\title{
ANALISIS MOTIVASI BELAJAR SISWA DALAM PEMBELAJARAN PENDIDIKAN KEWARGANEGARAAN
}

\author{
Agnesia Hartini, Asih Tresnaningsih \\ STKIP Persada Khatulitiwa, Studi Pendidikan Pancasila dan Kewarganegaraan, Sintang \\ E-mail: agnesiahartini21@yahoo.com, asihtrinanungsih@gmail.com
}

\begin{abstract}
The title of this study is "Analysis of Student Motivation in Learning Process of Citizenship Education Class IX in State Junior High School 4 Tebelian River". The research method used in this research is qualitative and descriptive research form. Data collection techniques used direct observation techniques, direct communication techniques, and documentation study techniques. The results of this study show that: 1) Based on the Analysis of Student Motivation in Learning Process of Citizenship Education Class IX in State Junior High School 4 Tebelian River Lesson $2019 / 2020$ year on the results of research, obtained a picture that is in providing motivation to learn to students in the learning process Education Citizenship is categorized as low. 2) Measuring student's motivation based on activity that is $59 \%$ is categorized as low, response is $50 \%$ and student attendance that is $96 \%$ can be categorized very high. 3) Research on Student Motivation Analysis Analysis in Learning Process of Citizenship Education Class IX in State Junior High School 4 Tebelian River Lesson Year 2019/2020 which has been done by using data collection instrument in the form of observation, interview and documentation can be seen that there are still students who can not independent and responsible in the process of learning Civics.
\end{abstract}

Keywords: Student Motivation, Civic Learning. 
Jurnal PEKAN Vol. 5 No.1 Edisi April 2020 Agnesia.H \& Asih.T, Analisis...71

\begin{abstract}
Abstrak
Judul penelitian ini adalah "Analisis Motivasi Belajar Siswa dalam Proses Pembelajaran Pendidikan Kewarganegaraan Kelas IX di Sekolah Menengah Pertama Negeri 4 Sungai Tebelian”. Metode Penelitian yang digunakan dalam penelitian ini kualitatif dan bentuk penelitian deskriptif. Teknik pengumpulan data menggunakan teknik observasi langsung, teknik komunikasi langsung, dan teknik studi dokumentasi. Hasil penelitian ini menunjukan bahwa: 1) Berdasarkan Analisis Motivasi Belajar Siswa dalam Proses Pembelajaran Pendidikan Kewarganegaraan Kelas IX di Sekolah Menengah Pertama Negeri 4 Sungai Tebelian Tahun Pelajaran 2019/2020 pada hasil penelitian, diperoleh gambaran yaitu dalam memberikan motivasi belajar pada siswa dalam proses pembelajaran Pendidikan Kewarganegaraan dikategorikan rendah. 2) Pengukuran motivasi belajar siswa berdasarkan aktivitas yaitu 59\% dikategorikan rendah, respon yaitu 50\% dan kehadiran siswa yaitu 96\% dapat dikategorikan sangat tinggi. 3) PenelitianAnalisis Motivasi Belajar Siswa dalam Proses Pembelajaran Pendidikan Kewarganegaraan Kelas IX di Sekolah Menengah Pertama Negeri 4 Sungai Tebelian Tahun Pelajaran 2019/2020 yang telah dilakukan dengan menggunakan instrumen pengumpulan data berupa observasi, wawancara dan dokumentasi dapat dilihat bahwa masih terdapat siswa yang belum bisa mandiri dan bertanggung jawab dalam proses pembelajaran PKn.
\end{abstract}

Kata Kunci: Motivasi Belajar Siswa, Pembelajaran PKn.

ISSN: $2540-8038$ 


\section{A. Pendahuluan}

Sejak dikeluarkannya Undangundang Nomor 20 Tahun 2003 tentang Sistem Pendidikan Nasional, maka sudah menjadi kewenangan sekolah untuk dapat meningkatkan kualitas belajar peserta didik agar dapat terlaksana dengan baik.Oleh karena itu diperlukan pengelolaan atau cara yang digunakan dengan metode-metode yang menyegarkan sehingga peserta didik dapat memperoleh penyegaran dalam hal pembelajarandisekolah. Upaya penggunaan metode-metode di sekolah bisa menjadi motivasi tersendiri bagi siswa dalam mengikuti pelajaran di sekolah. Motivasi siswa dalam belajar sangat mempengaruhi niat siswa dalam mengikuti proses pembelajaran termasuk dalam proses pembelajaran PKn. Menurut Mc. Donald (dalamSardiman 2014 : 73) "motivasiadalahperubahanenergidal amdiriseseorangditandaidenganmun culnya "feeling" dan didahului dengan tanggapan adanya tujuan”. Selanjutnya Suprijono (2009: 163) mengemukakan "motivasi belajar adalah proses yang memberi semangat belajar, arah, dan kegigihan perilaku." Artinya perilaku termotivasi adalah perilaku yang penuh energi, terarah dan tahan lama, ataupun dapat juga di definisikan sebagai daya dorong yang mengakibatkan seseorang mau dan rela untuk menggerakan kemampuan, tenaga dan waktunya dalam rangka pencapaian tujuan. Motivasi juga era tkaitannya dengan perasaan dan tingkah laku. Motivasi merupakan dorongan yang timbul pada diri seseorang secara sadar untuk melakukan suatu tindakan dengan tujuan tertentu (KBBI, 2008: 930).

Masalah lemahnya motivasi siswa dalam belajar pada saat proses pembelajaran PKn terlihat dari pertama yaitu seperti kurang aktifnya siswa jika diberikan pertanyaan, dan ketika guru sedang menjelaskan, siswa sibuk berbicara dengan temannya. Kedua, ketika siswa diberikan diskusi siswa terlihat kurang menanggapi dengan ISSN: 2540 - 8038 
apa yang telah dijelaskan oleh guru sehingga siswa selalu meminta guru menjelaskan berulang-ulang kali. Ketiga, siswa jika diberi persoalan atau permasalahan yang harus di tanggapi, siswa sangat sulit dalam memberikan pendapatnya untuk memecahkan masalah tersebut. Karena hal itulah, terdapat siswa yang tidak tuntas dalam mengerjakan ulangan harian maupun ulangan tengah semester.

Oleh sebab itu, motivasi sangat penting dalam proses pembelajaran. Dengan adanya motivasi, semangat belajar siswa jadi terdorong dan tergerak untuk menjadi lebih baik sehingga tujuan yang diinginkan oleh peserta didik dapat tercapai sesuai dengan tujuan pendidikan.

Untuk itu, pada penelitian ini penulis ingin meneliti bagaimana motivasi belajar siswa dalam proses pembelajaran pada bidang studi PKn terutama di SMP Negeri 4 Sungai Tebelian, khususnya di kelas IX, sebab PKn bukan mata pelajaran sejarah seperti bidang studi lainnya. Maka hal yang sangat substansial yang harus dipelajari adalah bagaimana penanaman moral pada siswa sejak dini. Karena motivasi merupakan salah satu factor penunjang keberhasilan proses belajar. Maka motivasi belajar siswa pada proses pembelajaran PKn ini perlu mendapat perhatian khusus.

Oleh Karena itu, motivasi dalam proses belajar siswa harus diperhatikan dengan seksama, sehingga siswa mempunyai motivasi dan minat untuk mengikuti proses pembelajaran Pkn. Dalam proses pembelajaran PKn diamati bahwa masih banyak kendala yang dihadapi siswa dan guru, diantaranya guru mata pelajaran PKn masih mengalami kesulitan dalam mengaktifkan siswa untuk terlibat langsung dalam proses penggalian dan penelaahan bahan pelajaran. Selain itu pula ada sebagian siswa memandang mata pelajaran PKn sebagai mata pelajaran yang bersifat konseptual dan teoritis. Akibatnya ketika siswa mengikuti pembelajaran PKn mereka merasa biasa-biasa saja dan tidak menganggap penting mata 
pelajaran tersebut. Sehingga siswa sering berbicara sendiri dengan teman-temannya dan mengantuk bahkan tertidur saat proses pembelajaran PKn berlangsung.

Penelitian ini dilakukan penulis di SMP Negeri 4 Sungai Tebelian dikarenakan ketika praobservasi terdapat masalah yang sering dialami siswa yaitu salah satunya memiliki motivasi belajar yang rendah

Berdasarkan dari latar belakang yang telah diuraikan diatas maka penulis tertarik untuk melakukan sebuah penelitian dengan judul “Analisis Motivasi Belajar Siswa dalam Proses Pembelajaran Pendidikan Kewarganegaraan Kelas IX di Sekolah Menengah Pertama Negeri 4 Sungai Tebelian Tahun Pelajaran 2019/2020”.

\section{B. Metode}

Metode yang digunakan pada penelitian ini yaitu metode penelitian kualitatif dengan pendekatan deskripsi analitik. Metode kualitatif dengan pendekatan deskriptif dipandang cocok untuk menjelaskan realitas yang terjadi dalam proses pembelajaran.

Dalam penelitian ini peneliti menggunakan bentuk penelitian kualitatif yang bersifat deskriptif. Sukamadita (2009:94) mengatakanbawa "penelitian kualitatif ditujukan untuk memahami fenomena-fenomena social dari sudut atau prespektif partisipan."Partisipan adalah orang-orang yang diajak berwawancara, diobservasi, diminta memberikan data, pendapat, pemikiran dan presepsinya.

Selain itu, peneliti juga dituntut agar mampu memilih bentuk dari penelitian yang akan dilaksanakan, dengan demikian maka data yang diperoleh akan lebih mendalam dan menyeluruh sehingga tujuan penelitian akan dapat tercapai. Menurut Sukmadinata (2009: 72),Penelitian deskriptif adalah suatu bentuk penelitian yang ditujukan untuk mendeskripsikan feonomenafenomena yang ada, baik ISSN: $2540-8038$ 
fenomena alamiah maupun fenomena buatan manusia.

Fenomena itu bisa berupa bentuk, aktivitas, karakteristik, perubahan, hubungan, kesamaan dan perbedaan antara fenomena yang satu dengan fenomena lainnya.

Dari penjelasam tersebut dapat disimpulkan bahwa penelitian deskriptif merupakan bentuk penelitian yang menunjukan fenomena-fenomena alamiah maupun buatan manusia.

\section{Pembahasan Dan Hasil \\ 1. Pemahasan}

\section{a. Motivasi Belajar}

Motivasi belajar
dapat timbul karena faktor
intrinsik, berupa hasrat dan
keinginan berhasil dan dorongan
kebutuhan belajar, harapan akan
cita-cita. Sedangkan faktor
ekstrinsiknya adalah adanya
penghargaan, lingkungan belajar
yang kondusif, dan kegiatan
belajar yang menarik.Tetapi harus
diingat, kedua faktor tersebut
disebabkan oleh rangsangan
tertentu, sehingga seseorang

berkeinginan untuk melakukan aktivitas belajar yang lebih giat dan semangat.

Menurut Hamzah (2011: 23) "hakikat motivasi belajar adalah dorongan internal dan eksternal pada siswa-siswa yang sedang belajar untuk mengadakan perubahan tingkah laku, pada umumnya dengan beberapa indikator atau unsur yang mendukung."Hal itu mempunyai peranan besar dalam keberhasilan seseorang dalam belajar. Menurut Fathurohman dan Sutikno (2009: 13)"seseorang yang tidak mempunyai motivasi dalam belajar, tidak akan mungkin melakukan aktivitas belajar." Sedangkan Menurut Iskandar (2011: 23)"motivasi belajar adalah daya penggerak dari dalam diri individu untuk melakukan kegiatan belajar untuk menambah pengetahuan dan keterampilan serta pengalaman."Dapat disimpulkan, dengan adanya usaha yang tekun dan terutama didasari adanya motivasi, maka seseorang yang belajar itu akan dapat melahirkan ISSN: 2540 - 8038 
prestasi yang baik. Intensitas motivasi seorang siswa akan sangan menentukan tingkat pencapaian prestasi belajarnya.

\section{b. Proses Pembelajaran}

Pembelajaran merupakan proses kegiatan belajar mengajar yang juga berperan dalam menentukan keberhasilan belajar siswa. Proses pembelajaran ituakan terjadi sebuah kegiatan timbal balik antara guru dengan siswa untuk menuju tujuan yang lebih baik. Oleh karena itu, proses pembelajaran musik yang tepat di ekstra kurikuler sangat dibutuhkan dalam kegiatan berkesenian untuk menghasilkan sebuah musik (lagu) melalui aransemen yang pada akhirnya lagu tersebut terkesan baru dan siswa mampu untuk membawakan music denganbaik.

Menurut Winarno (2013: 218) pelaksanaan proses pembelajaran dan pelaksanaan pembelajaran. Persyaratan pelaksanaan proses pembelajaran meliputi hal-hal seperti: ketentuan tentang rombongan belajar, beban kerja minimal guru, buku teks pelajaran, dan pengelolaan kelas. Kegiatan pelaksanaan pembelajaran meliputi: kegiatan pendahuluan, inti dan penutup.

Dapat disimpulkan bahwa dalam proses pembelajaran, pengenalan terhadap diri sendiri atau kepribadian diri merupakan hal yang sangat penting dalam upayaupaya pemberdayaan diri (selfempowering).

\section{c. Pendidikan Kewarganegaraan}

Pendidikan Kewarganegaraan merupakan program pendidikan yang menekankan pada pembentukan warganegara agar dapat melaksanakan hak dan kewajiban. Sebagaimana disebutkan dalam Permendiknas Nomor 22 Tahun 2006. Menurut Zamroni (dalam A. Ubaedillah \& Abdul Rozak, 2013: 15) "Pendidikan Kewarhanegaraan merupakan pendidikan demokrasi yang bertujuan untuk mempersiapkan masyarakat berfikirkritis dan bertindak melalui dengan menanamkan kesadaran bahwa demokrasi adalah bentuk kehidupan yang menjamin hak masyarakat." 
Pendidikan kewarganegaraan dilakukan dengan kegiatan yang menyangkut pengalaman yang dikaitkan dengan kehidupan nyata seperti kehidupan dalam keluarga dan masyarakat. Berdasarkan beberapa pengertian di atas dapat disimpulkan bahwa PKn merupakan mata pelajaran yang memfokuskan pada pembentukan warganegara. Dalam pembelajaran di sekolah, pembelajaran PKn dapat dikaitkan dengan kehidupan sehari-hari.

\section{Hasil}

a. Proses Pembelajaran

Pendidikan Kewarganegaraan Kelas IX di SMP Negeri 4 Sungai Tebelian Tahun Pelajaran 2019/2020.

Berdasarkan hasil penelitian aktivitas siswa bahwa perkembangan aktivitas siswa hanya meningkat sedikit dalam kegiatan pembelajaran PKn, diperhatikan pada pertemuan pertama yaitu dengan perensentase $55 \%$ kemudian pada pertemua kedua naik dan menjadi $63 \%$. Jika di hitung rata-rata mulai dari pertemuan yang pertama dan kedua yaitu 59\% dari hasil penilaian tersebut dapat dikategorikan rendah oleh peneliti. Kemudian pada hasil penilaian respon siswa pada pertemuan pertama begitu rendah dengan persentase sebesar $52 \%$ dan pada pertemuan yang kedua menjadi lebih merosot jika dibandingkan dengan pertemuan yang bertama yaitu dengan peresntase nilai $49 \%$, dengan nilai rata-rata yaitu $50 \%$ yang dapat dikategorikan rendah. Hal ini banyak dipengaruhi oleh jumlah siswa yang tidak merespon saat materi disampaikan oleh guru, baik itu sedang bermain di dalam kelas dan ada pula yang tidur didalam kelas.

Selain itu, pada hasil penilaian kehadiran siswa pada pertemuan pertama sangat tinggi yaitu denganpersentase sebesar 96\% dan pada pertemuan kedua juga dengan kategori sangat tinggi yaitu 96\%, jika dihitung rata-rata berdasarkan penilaian persentase pada pertemuan yang pertama dan kedua maka nilai rata-rata ISSN: $2540-8038$ 
persentase sebesar $96 \%$ dan dapat dikategorikan sangat tinggi.

b. Motivasi Belajar Siswa dalam Proses Pembelajaran Pendidikan

Kewarganegaraan Kelas IX di SMP Negeri 4 Sungai Tebelian Tahun Pelajaran 2019/2020.

Dari faktor intrinsik yang peneliti amati aktivitas siswa didasari niat yang keras untuk mengejar cita-cita sehingga mereka mempersiapkan jadwal pelajaran, namun dapat dikatakan bahwa 30\% dari hasil perhitungan dikarenakan masih terdapat beberapa siswa yang malas dalam belajar, serta tidak disiplin dalam belajar. Sedangkan secara ekstrinsik dikarenakan adanya dukungan dari orang tua, guru dan lingkungan hal tersebut dapat memberikan motivasi kepada diri pribadi siswa untuk rajin belajar, jika dukungan itu kurang diberikan maka menjadikan siswa tersebut menjadi malas dalam belajar.

Secara intrinsik, respon siswa yang tinggi sebagian besar dipengaruhi rasa ingin tahu yang besar dan menganggap bahwa betapa pentingnya mata pelajaran PKn sehingga siswa menunjukan respon yang besar, namun secara ekstrinsik pengaruh tinggi atau rendahnya respon lebih besar dipengaruhi oleh lingkungan belajar baik teman, duru maupun orang tua. Pengaruh rendahnya respon siswa lebih banyak dikarenakan siswa tersebut malas dalam menggali ilmu dan suka bermain didalam kelas pada saat guru menyampaikan materi.

Pada penilaian kehadiran siswa, faktor intrinsik yang mempengaruhi tinggi rendahnya nilai kehadiran siswa dipengaruhi oleh diri pribadi siswa yaitu rasa semangat dalam menimba ilmu, namun secara eksternal karena rasa takut jika tidak hadir kesekolah, karena apabila tidak berangkat kesekolah mereka akan dimarahi orang tua maupun guru di sekolah, serta ketinggalan pelajaran dan juga dapat berpengaruh pada nilai raport mereka, bahkan jika kehadiran siswa buruk dikarenakan sering absen 
(tidak masuk tanpa surat izin) maka bias tidak naik kelas.

\section{c. Faktor yang Mempengaruhi}

Motivasi Belajar Siswa dalam

Proses Pembelajaran

Pendidikan Kewarganegaraan

Kelas IX di SMP Negeri 4

\section{Sungai Tebelian Tahun}

Pelajaran 2019/2020

Terdapat dua jenis faktor yang mendorong seseorang untuk berusaha mencapai kepuasan dan menjauhkan diri dari ketidakpuasan. Dua faktor itu dusebutnya faktor higiene(faktor ekstrinsik) dan faktor motivator (faktor intrinsik). Faktor higiene memotivasi seseorang untuk keluar dari ketidakpuasan, termasuk didalamnya adalaj hubungan antar manusia, imbalan, kondisi lingkungan, dan sebagainya (faktor ekstrinsik), sedangkan faktor motivator yaitu memotivasi seseorang berusaha menvapai kepuasan yang termasuk didalamnya adalah achievement, pengakuan, kemajuan tingkat kehidupan (faktor intrinsik).

Dari nilai amatan yaitu nilai rata-rata dari aktivitas siswa 59\%, nilai rata-rata respon siswa 50\%, dan nilai rata-rata kehadiran siswa sebesar 96\%. Jika dijumlahkan keseluruhan yaitu dengan nilai ratarata 59\%. Dapat dikategorikan Motivasi Belajar Siswa Kelas IX dalam Proses Pembelajaran Pendidikan Kewarganegaraan di Sekolah Menengah Pertama Negeri 4 Sungai Tebelian Tahun Pelajaran 2017/2018 rendah.

\section{Simpulan}

Berdasarkan hasil penelitian dan pembahasan. Dapat disimpulkan secara umum bahwa analisis motivasi belajar siswa dalam proses pembelajaran Pendidikan Kewarganegaraan kelas IX di Sekolah Menengah Pertama Negeri 4 Sungai Tebelian Tahun Pelajaran 2019/2020 dapat dikategorikan rendah.

\section{Daftar Pustaka}

Annurrahman, M.Pd. 2014. BelajardanPembelajaran. Bandung : Alfabeta.

Arikunto, S. 2010. Prosedur Penelitian: Suatu Pendekatan Ptaktik. Jakarta : PT Rineka Cipta. ISSN: 2540 - 8038 
Budiman. 2010. Motivasi Belajar Siswa dalam Proses Pembelajaran Pendidikan Kewarganegaraan kelas VIII di Sekolah Menengah Pertama Negeri 1 Suhaid Kabupaten Kapuas Hulu. STKIP Persada Khatulistiwa Sintang. Tidak Diterbitkan.

Hamzah B. Uno, M.Pd. 2011. TeoriMotivasi\&Pengukur annya. Jakarta : PT. Bumi Aksara.

Iskandar. 2009. Penelitian Tindakan Kelas. Jambi : Gaung Persada (GP) Pres.

Pupuh, Fathurrohman, M. Sobry Sutikno. 2009. Strategi Belajar Mengajar; Strategi Mewujudkan Pembelajaran Bermakna Melalui Penanaman Konsep Umum \& Konsep Islami. Bandung : Refika Aditama.
Sardiman, A. M. 2014. InteraksiMotivasi\&Belaja rMengajar. Jakarta : Rajawali Pers.

Sukmadinata, 2009. MetodologiPenelitianKua litatif. Jakarta : Rineka Cipta.

Undang-undang No. 20 Tahun 2003 tentang Sistem Pendidikan Nasional. Jakarta. Sekretariat Negara.

Winarno. 2013. Pembelajaran PendidikanKewarganegara an. Jakarta. Sinar Grafika. 